\title{
Anaerobic degradability and acid hydrolysis of organic manure as an illustration of dietary organic matter utilization in cows in relation to lactation period
}

\author{
Radka Váchalová1, Ladislav Koláŕ ${ }^{1}$, Jan Frelich ${ }^{1}$, Jan Váchal ${ }^{1}$, Kateřina Volfová1, \\ Milan Kobes ${ }^{1}$, Václav Kudrna ${ }^{2}$, Petr Homolka², Petr Marada ${ }^{3}$, Miroslav Dumbrovský ${ }^{4}$ \\ ${ }^{1}$ University of South Bohemia in České Budějovice, Agricultural Faculty, České Budějovice, Czech Republic \\ ${ }^{2}$ Research Institute of Animal Production in Prague-Uhříněves, Praha Uhříněves, Czech Republic \\ ${ }^{3}$ Mendel University in Brno, Faculty of Agronomy, Department of Agriculture, \\ Food and Environmental Engineering, Brno, Czech Republic \\ ${ }^{4}$ Brno University of Technology, Faculty of Civil Engineering, \\ Institute of Landscape Water Management, Brno, Czech Republic
}

\section{Received March 18, 2014}

Accepted July 23, 2014

\begin{abstract}
The objective of the present paper was to verify whether the method of studying the anaerobic degradability of organic matter of excrements could reveal the utilization of dietary organic matter in the digestive tract of ruminants in relation to the lactation period, and whether it could be replaced by a cheaper and easier method of acid hydrolysis of excrements. Changes in anaerobic degradability and hydrolysis yields of excrements were investigated in an experimental herd of 30 cows divided into two groups differing in their lactation period by 30 days. The results document that anaerobic degradability is a suitable indicator of anaerobic digestion conditions in the digestive tract of animals and of the fitness of their organism. However, the results of excrement hydrolysis according to the Rovira and Vallejo (2002) method were hardly reproducible and so they could not be used, when only the very labile organic fraction is evaluated. The evaluation of the sum of very labile fractions and semi-labile fraction provides easily available values, but these are only orientative values that cannot replace the costly and labour-consuming determination of anaerobic degradability of excrements.
\end{abstract}

Lactation, excrements, organic matter, digestive tract

Organic matter degradability was investigated mainly from the aspect of resistance during acid hydrolysis (Rovira and Vallejo 2002; Shirato and Yokozawa 2006) or oxidation (Blair et al. 1995; Chan et al. 2001).

The results of studies aimed at anaerobic degradability (Süssmuth et al. 1999) of organic matter of excrements as an illustration of their quality in relation to the condition of the digestive tract of ruminants at a steady state (Kolář et al. 2010) allow a substantial enlargement of the sets of studied experimental variants because the Oxi Top Control (Merck device) with its OC 100 controller and the ACHAT OC programme make it possible to study 360 variants at the same time. However, it is hindered by the extremely high cost of this equipment for the time being because in the Czech Republic only the experimental containers with measuring heads with infrared interface amount to 3.6 million Czech Crowns. For this reason we wanted to answer the question whether anaerobic degradability of organic matter could be replaced for this purpose by determination of the ratio of organic matter labile to stable fractions. It would be very advantageous for practical conditions because the above-mentioned oxidation and hydrolytic methods are much cheaper.

The process of anaerobic digestion of organic matter takes place in several phases with the participation of various groups of microorganisms in anaerobic environment (Baresi et al. 1978) in many forms spontaneously in nature (Garcia et al. 2000); the four fully linked phases are hydrolysis, acidogenesis, acetogenesis, and methanogenesis (Gujer

Address for correspondence:

Prof. Ing. Ladislav Kolár̆, DrSc. 
and Zehnder 1983). The hydrolytic phase consists in organic matter depolymerisation by hydrolytic enzymes (Kaseng et al. 1992); acidogenesis consists in transformation of hydrolysis products to lower organic acids and $\mathrm{CO}_{2}$ and $\mathrm{H}_{2}$ and lower alcohols (Kalyuzhnyi et al. 2000); acetogenesis is characterized by transformation of higher fatty acids to anions of acetic acid, formic acid, $\mathrm{CO}_{2}$ and $\mathrm{H}_{2}$ (Salminen et al. 2000); methanogenesis is the production of methane from anions of $\mathrm{CH}_{3} \mathrm{COO}^{-}, \mathrm{HCOO}^{-}, \mathrm{H}_{2}, \mathrm{CO}_{2}$, methanol, and methylamines (Hwang et al. 2001). The sequence of reactions during digestion of ruminants is identical (Gijzen 1998).

Table 1. Breeding cows included in group A.

\begin{tabular}{rlrrrrr}
\hline Cow No. & Breed & Birth date & Lactation No. & Weight at calving & $\begin{array}{c}\text { Efficiency } \\
\text { per lactation }(\mathrm{kg})\end{array}$ & Group \\
\hline 71 & Holstein & $28 / 7 / 2007$ & 1 & 576 & 9715 & $\mathrm{~A}$ \\
155 & Holstein & $22 / 6 / 2007$ & 1 & 638 & 10143 & $\mathrm{~A}$ \\
163 & Holstein & $29 / 6 / 2007$ & 1 & 552 & 9899 & $\mathrm{~A}$ \\
182 & Holstein & $28 / 5 / 2007$ & 1 & 571 & 8853 & $\mathrm{~A}$ \\
148 & Holstein & $12 / 9 / 2006$ & 2 & 571 & 11174 & $\mathrm{~A}$ \\
254 & Holstein & $18 / 5 / 2006$ & 2 & 555 & 7637 & $\mathrm{~A}$ \\
265 & Holstein & $19 / 8 / 2006$ & 2 & 520 & 9797 & $\mathrm{~A}$ \\
82 & Holstein & $3 / 8 / 2005$ & 3 & 655 & 10014 & $\mathrm{~A}$ \\
134 & Holstein & $5 / 8 / 2005$ & 3 & 646 & 4742 & $\mathrm{~A}$ \\
159 & Holstein & $16 / 7 / 2005$ & 3 & 667 & 9395 & $\mathrm{~A}$ \\
169 & Holstein & $5 / 6 / 2005$ & 3 & 643 & 6559 & $\mathrm{~A}$ \\
237 & Holstein & $17 / 3 / 2006$ & 3 & 598 & 9648 & $\mathrm{~A}$ \\
1 & Holstein & $27 / 5 / 2004$ & 4 & 696 & 9714 & $\mathrm{~A}$ \\
59 & Czech Pied & $19 / 8 / 2007$ & 1 & 527 & 7455 & $\mathrm{~A}$ \\
115 & Czech Pied & $26 / 4 / 2005$ & 3 & 695 & 6793 & $\mathrm{~A}$ \\
\hline
\end{tabular}

Table 2. Breeding cows included in group B.

\begin{tabular}{|c|c|c|c|c|c|c|}
\hline Cow No. & Breed & Birth date & Lactation No. & Weight at calving & $\begin{array}{c}\text { Efficiency } \\
\text { per lactation }(\mathrm{kg})\end{array}$ & Group \\
\hline 44 & Holstein & $2 / 9 / 2007$ & 1 & 587 & 13475 & B \\
\hline 138 & Holstein & $5 / 8 / 2007$ & 1 & 595 & 7800 & B \\
\hline 167 & Holstein & $6 / 3 / 2007$ & 1 & 555 & 8042 & B \\
\hline 208 & Holstein & $5 / 9 / 2007$ & 1 & 507 & 8553 & B \\
\hline 63 & Holstein & $18 / 6 / 2006$ & 2 & 617 & 11892 & B \\
\hline 78 & Holstein & $18 / 10 / 2006$ & 2 & 526 & 8568 & B \\
\hline 135 & Holstein & $16 / 7 / 2006$ & 2 & 697 & & $\mathrm{~B}$ \\
\hline 177 & Holstein & $19 / 8 / 2006$ & 2 & 662 & 8093 & $\mathrm{~B}$ \\
\hline 230 & Holstein & $6 / 7 / 2006$ & 2 & 618 & 10102 & $\mathrm{~B}$ \\
\hline 13 & Holstein & $6 / 2 / 2005$ & 3 & 606 & 10993 & $\mathrm{~B}$ \\
\hline 164 & Holstein & $24 / 12 / 2004$ & 3 & 592 & 9662 & $\mathrm{~B}$ \\
\hline 43 & Czech Pied & $26 / 11 / 2005$ & 3 & 676 & 9167 & $\mathrm{~B}$ \\
\hline 51 & Czech Pied & $16 / 12 / 2003$ & 4 & 785 & 7820 & $\mathrm{~B}$ \\
\hline 188 & Czech Pied & $12 / 7 / 2006$ & 2 & 716 & 3670 & $\mathrm{~B}$ \\
\hline
\end{tabular}




\section{Materials and Methods}

The experiment was conducted in the experimental barn of the Research Institute of Animal Production in Prague-Uhř́něves. The experimental herd consisted of 30 cows, divided into two groups. The time of three weeks from the start of the experiment served only to reach a steady state. The cows were divided into two groups, group A (period 1) and control group B (period 2). Period 1 and 2 differed in the 30-day lactation period (Tables 1 and 2).

Excrement samples were taken directly from the rectum of experimental animals in order to ensure correct identification of samples and minimum contamination of samples from the ambient environment. The collected samples were fast-desiccated at reduced pressure at a temperature of $60^{\circ} \mathrm{C}$ and then dried at the same temperature for $48 \mathrm{~h}$. Before drying the samples were preserved at a temperature of $-20^{\circ} \mathrm{C}$. Feed samples were treated in the same way.

Acid hydrolysis of organic matter and excrements was performed according to Shirato and Yokozawa (2006), who adapted the original method of Rovira and Vallejo (2002) designed for the evaluation of hydrolyzability of soil organic matter and any plant material. The method consists in hydrolysis of samples in a pyrex tube with $24.58 \% \mathrm{H}_{2} \mathrm{SO}_{4}$ at a temperature of $105{ }^{\circ} \mathrm{C}$ for $30 \mathrm{~min}$ (easily hydrolyzable fraction LPI is hydrolyzed); in the same tube hydrolysis with $75.92 \% \mathrm{H}_{2} \mathrm{SO}_{4}$ at a temperature of $20{ }^{\circ} \mathrm{C}$, and with $10.1 \% \mathrm{H}_{2} \mathrm{SO}_{4}$ at a temperature of $105^{\circ} \mathrm{C}$ takes place for $1 \mathrm{~h}$ (semi-hydrolyzable fraction LPII is hydrolyzed). Organic matters in the rinsed residue are a hardly hydrolyzable fraction LPIII. The result is evaluated by the percentage carbon proportion of particular fractions in the total carbon content of the sample. It is to note that this is the habitual method, and any modifications of the method, e.g. replacing the difficult work in a pyrex tube by partial hydrolyses in larger vessels, provide completely incorrect results.

Anaerobic degradability is expressed by this relation:

$\mathrm{D}_{\mathrm{c}}=\frac{\mathrm{C}_{\mathrm{g}}}{\mathrm{C}_{\mathrm{s}}} \cdot 100$

$\mathrm{C}_{\mathrm{s}}=$ total content of $\mathrm{C}$ in the sample

$\mathrm{C}_{\mathrm{g}}^{\mathrm{s}}=\mathrm{C}$ content in methane released during the measurement of anaerobic degradability (Straka et al. 2009)

The analytical method of determining anaerobic degradability of excrements was evaluated by determination of the interval of reliability of the mean. It is advantageous to use for several-element sets the method according to Dean and Dixon (Eckschlager et al. 1980) based on the range (R) of results. An acid hydrolytic procedure according to Shirato and Yokozawa (2006) was performed in parallel in these tests.

Measurements of soil organic carbon

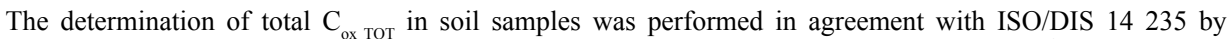
spectrophotometry after oxidation with $0.27 \mathrm{M} \mathrm{K}_{2} \mathrm{Cr}_{2} \mathrm{O}_{7}$ in concentrated $\mathrm{H}_{2} \mathrm{SO}_{4}\left(\mathrm{~d}=1.84 \mathrm{~g} / \mathrm{cm}^{3}\right)$ at $135^{\circ} \mathrm{C}$ for $30 \mathrm{~min}$.

Fractions of soil carbon were determined in agreement with commonly used methods: C-substances $\left(\mathrm{C}_{\text {hws }}\right)$ dissolving in hot water according to the Körschens et al. (1990), fractions of C-substances based on the degree of their stability during acid hydrolysis according to Shirato and Yokozawa (2006) and during oxidation with modified Walkley-Black method according to Walkley (1947).

Humic acids (HA) and fulvic acids (FA) were isolated after extraction of soil samples with a mixture solution of $0.1 \mathrm{M} \mathrm{Na}_{4} \mathrm{P}_{2} \mathrm{O}_{7} \cdot 10 \mathrm{H}_{2} \mathrm{O}+\mathrm{NaOH}$ by precipitation with $\mathrm{H}_{2} \mathrm{SO}_{4}$ and separation of HA:FA using the classical method by Kononová and Bělčíková (1963). Carbon in HA and FA was again determined using the method according to ISO/DIS 14235.

\section{Results and Discussion}

The results in Table 3 document the high reproducibility of acid hydrolysis of excrements, a small range of the variation of results and a small standard deviation. As an analytical method, it is obviously preferable to anaerobic degradability $\left(D_{c}\right)$, the results of which have the range and standard deviation higher more than three times. But results in Table 3 show that the sensitivity of acid hydrolysis is very low. This method did not register at all a change in the lactation period by 30 days and associated changes in organic matter utilization in the digestive tract of an animal.

Table 4 shows that anaerobic degradability substantially decreases with a 30-day difference in the lactation period; In conclusion we can say, that the regeneration of the digestive tract of the animals made progress and therefore the activity of the digestive tract as an anaerobic reactor was improved. 
Table 3. Testing of analytical methods - determination of anaerobic degradability and acid hydrolysis in excrements of animal No. 82 from single sampling, in period 1 and in period 2 longer by 30 days of lactation.

\begin{tabular}{|c|c|c|c|c|c|c|c|c|c|c|c|c|}
\hline & \multirow{2}{*}{ Period } & \multicolumn{8}{|c|}{ Sample } & \multirow{2}{*}{$\mathrm{R}$} & \multirow{2}{*}{$\mathrm{S}_{\mathrm{R}}$} & \multirow{2}{*}{$\mathrm{L}_{1,2}$} \\
\hline & & 1 & 2 & 3 & 4 & 5 & 6 & 7 & 8 & & & \\
\hline $\mathrm{Dc}$ & 1 & 32.3 & 38.4 & 35.4 & 36.7 & 39.1 & 38.2 & 37.7 & 34.9 & 6.8 & 2.38 & $36.6 \pm 2.0$ \\
\hline$\left(\% \mathrm{C}_{\mathrm{tot}}\right)$ & 2 & 26.2 & 31.5 & 28.4 & 29.4 & 32.3 & 30.7 & 33.2 & 35.1 & 8.9 & 3.12 & $30.8 \pm 2.6$ \\
\hline LPI & 1 & 4.1 & 3.9 & 3.8 & 4.3 & 4 & 3.9 & 4.1 & 4.2 & 0.4 & 0.14 & $4.0 \pm 0.1$ \\
\hline$\left(\% \mathrm{C}_{\mathrm{tot}}\right)^{-}$ & 2 & 4.2 & 4 & 4.1 & 3.9 & 4 & 3.7 & 3.9 & 3.8 & 0.5 & 0.18 & $4.0 \pm 0.1$ \\
\hline$\overline{\text { LPII }}$ & 1 & 34.5 & 34.1 & 34.6 & 35.4 & 33.8 & 34 & 35.1 & 34.9 & 1.6 & 0.56 & $34.5 \pm 0.5$ \\
\hline$\left(\% \mathrm{C}_{\text {tot }}\right)^{-}$ & 2 & 32.1 & 34 & 33.2 & 33.7 & 32.8 & 33.9 & 32.7 & 32.5 & 1.9 & 0.67 & $33.1 \pm 0.6$ \\
\hline$\overline{\text { LPIII }}$ & 1 & 61.4 & 62 & 61.6 & 60.3 & 62.2 & 62.1 & 60.8 & 60.9 & 1.8 & 0.63 & $61.4 \pm 0.5$ \\
\hline$\left(\% \mathrm{C}_{\text {tot }}\right)$ & 2 & 63.7 & 62 & 62.7 & 62.4 & 63.2 & 62.4 & 63.4 & 63.7 & 1.7 & 0.6 & $62.9 \pm 0.5$ \\
\hline
\end{tabular}

$\mathrm{D}_{\mathrm{c}}$ - anaerobic degradability; $\mathrm{R}$ - range, $\mathrm{L}_{12}$ - interval of reliability of the mean at $P=0.05\left(\mathrm{~L}_{12}=\overline{\mathrm{x}} \pm \mathrm{K}\right.$ 趾; $\left.\mathrm{K}_{\mathrm{n}}(\mathrm{n}=8)=0.29(P=0.05)\right) ; \mathrm{S}_{\mathrm{R}}-$ standard deviation from the range $\left(\mathrm{S}_{\mathrm{R}}=\mathrm{k}_{\mathrm{n}} \cdot \mathrm{R} ; \mathrm{k}_{\mathrm{n}}(\mathrm{n}=8)=0.351\right) ; \mathrm{LPI}-$ labile fraction; LPII - semi-labile fraction; LPIII - stable fraction

Table 4. Anaerobic degradability and acid hydrolysis of excrements in period 1 and in period 2 longer by 30 days of lactation in five successive samples in three experimental animals at a steady state.

\begin{tabular}{|c|c|c|c|c|c|c|c|c|c|c|}
\hline & \multirow{2}{*}{\multicolumn{2}{|c|}{ Animal No. Period }} & \multicolumn{5}{|c|}{ Sampling } & \multirow[t]{2}{*}{$\mathrm{R}$} & \multirow[t]{2}{*}{$\mathrm{S}_{\mathrm{R}}$} & \multirow{2}{*}{$\mathrm{L}_{1,2}$} \\
\hline & & & 1 & 2 & 3 & 4 & 5 & & & \\
\hline \multirow{6}{*}{$\operatorname{Dc}\left(\% \mathrm{C}_{\mathrm{tot}}\right)$} & \multirow{2}{*}{82} & 1 & 35.2 & 36 & 38.3 & 34.9 & 32.5 & 5.8 & 2.49 & $35.4 \pm 3.0$ \\
\hline & & 2 & 29.4 & 30.7 & 26.2 & 29.9 & 30.4 & 4.5 & 1.93 & $29.3 \pm 2.3$ \\
\hline & \multirow{2}{*}{134} & 1 & 41.7 & 38.2 & 40 & 36.4 & 32.9 & 8.8 & 3.78 & $37.8 \pm 4.5$ \\
\hline & & 2 & 33.3 & 30.3 & 29.4 & 28.1 & 31.5 & 5.2 & 2.24 & $30.5 \pm 2.7$ \\
\hline & \multirow{2}{*}{237} & 1 & 28.4 & 27.2 & 32.6 & 27.1 & 30 & 5.5 & 2.36 & $29.1 \pm 2.8$ \\
\hline & & 2 & 24.7 & 21.5 & 20.1 & 22.3 & 23.9 & 4.6 & 1.98 & $22.5 \pm 2.3$ \\
\hline \multirow{6}{*}{ LPI $\left(\% \mathrm{C}_{\text {tot }}\right)$} & \multirow{2}{*}{82} & 1 & 3.8 & 3.9 & 3.9 & 3.8 & 3.8 & 0.1 & 0.04 & $3.8 \pm 0.0$ \\
\hline & & 2 & 3.7 & 3.9 & 3.8 & 3.8 & 3.9 & 0.2 & 0.09 & $3.8 \pm 0.1$ \\
\hline & \multirow{2}{*}{134} & 1 & 3.7 & 3.8 & 3.7 & 3.9 & 3.8 & 0.2 & 0.09 & $3.8 \pm 0.1$ \\
\hline & & 2 & 3.6 & 3.8 & 3.6 & 3.8 & 3.7 & 0.02 & 0.09 & $3.7 \pm 0.1$ \\
\hline & \multirow{2}{*}{237} & 1 & 3.8 & 3.7 & 3.7 & 3.6 & 3.7 & 0.2 & 0.09 & $3.7 \pm 0.1$ \\
\hline & & 2 & 3.8 & 3.8 & 3.7 & 3.7 & 3.8 & 0.1 & 0.04 & $3.8 \pm 0.0$ \\
\hline \multirow{6}{*}{ LPII $\left(\% \mathrm{C}_{\text {tot }}\right)$} & \multirow{2}{*}{82} & 1 & 34.2 & 35.2 & 33.8 & 34.9 & 35.4 & 1.6 & 0.69 & $34.7 \pm 0.8$ \\
\hline & & 2 & 33.3 & 33.9 & 34.8 & 35.1 & 36.2 & 2.9 & 1.25 & $34.7 \pm 1.5$ \\
\hline & \multirow{2}{*}{134} & 1 & 37.6 & 38.2 & 35.2 & 36.4 & 38.1 & 3 & 1.29 & $37.1 \pm 1.5$ \\
\hline & & 2 & 38.5 & 38.8 & 39.9 & 36.8 & 37.4 & 3.1 & 1.33 & $38.3 \pm 1.6$ \\
\hline & \multirow{2}{*}{237} & 1 & 32.7 & 31.8 & 33.1 & 30.8 & 32.5 & 2.3 & 0.99 & $32.2 \pm 1.2$ \\
\hline & & 2 & 31.7 & 33.3 & 34.9 & 35.1 & 32.9 & 3.4 & 1.46 & $33.6 \pm 1.7$ \\
\hline \multirow{6}{*}{ LPIII $\left(\% \mathrm{C}_{\text {tot }}\right)$} & \multirow{2}{*}{82} & 1 & 62 & 60.9 & 62.3 & 61.3 & 60.8 & 1.5 & 0.64 & $61.5 \pm 0.8$ \\
\hline & & 2 & 63 & 62.2 & 61.4 & 61.1 & 59.9 & 3.1 & 1.33 & $61.5 \pm 1.6$ \\
\hline & \multirow{2}{*}{134} & 1 & 58.7 & 58 & 61.1 & 59.7 & 58.1 & 3.1 & 1.33 & $59.1 \pm 1.6$ \\
\hline & & 2 & 58.9 & 57.4 & 56.5 & 59.4 & 58.9 & 2.9 & 1.25 & $58.2 \pm 1.5$ \\
\hline & \multirow{2}{*}{237} & 1 & 63.5 & 74.5 & 63.2 & 65.6 & 63.8 & 2.4 & 1.03 & $64.1 \pm 1.2$ \\
\hline & & 2 & 64.5 & 62.9 & 61.4 & 61.2 & 63.3 & 3.3 & 1.42 & $62.7 \pm 1.7$ \\
\hline
\end{tabular}

$\mathrm{D}_{\mathrm{c}}$ - anaerobic degradability; $\mathrm{R}$ - range, $\mathrm{L}_{1,2}-$ interval of reliability of the mean at $P=0.05 ;\left(\mathrm{L}_{1,2}=\overline{\mathrm{x}} \pm \mathrm{K}_{\mathrm{n}} \cdot \mathrm{R} ; \mathrm{K}_{\mathrm{n}}(\mathrm{n}=5)=\right.$ $0.430(P=0.05)) ; \mathrm{S}_{\mathrm{R}}$ - standard deviation from the range $\left(\mathrm{S}_{\mathrm{R}}=\mathrm{k}_{\mathrm{n}} \cdot \mathrm{R} ; \mathrm{k}_{\mathrm{n}}(\mathrm{n}=8)=0.351\right)$; LPI - labile fraction; LPII - semilabile fraction; LPIII - stable fraction 
Table 5. The influence of inoculum quality on determination of anaerobic demonstrated by the use of three different inocula for determination of anaerobic degradability of excrements in three experimental animals at a steady state in period 2 of group A.

\begin{tabular}{|c|c|c|c|c|c|c|}
\hline & Inoculum & Animal No. & $\mathrm{R}$ & $\mathrm{S}_{\mathrm{R}}$ & $\mathrm{L}_{12}$ & Order of anaerobic degradability \\
\hline & & 82 & 4.5 & 1.93 & 29.3-2.3 & \\
\hline & A & 134 & 5.2 & 2.24 & $30.5-2.7$ & $134>82>237$ \\
\hline & & 237 & 4.6 & 1.98 & $22.5-2.3$ & \\
\hline & & 82 & 2.9 & 1.25 & $25.1-1.5$ & \\
\hline \multirow[t]{5}{*}{$\operatorname{Dc}\left(\% \mathrm{C}_{\mathrm{tot}}\right)$} & B & 134 & 4.1 & 1.76 & $32.6-2.1$ & $134>82>237$ \\
\hline & & 237 & 4.8 & 2.06 & $16.4-2.4$ & \\
\hline & & 82 & 6.2 & 2.66 & $24.1-3.2$ & \\
\hline & $\mathrm{C}$ & 134 & 7.4 & 3.18 & $26.3-3.8$ & $134>82>237$ \\
\hline & & 237 & 5.5 & 2.36 & $28.9-2.8$ & \\
\hline
\end{tabular}

$\mathrm{D}_{\mathrm{c}}$ - anaerobic degradability; $\mathrm{R}$ - range, $\mathrm{L}_{1}{ }_{2}-$ interval of reliability of the mean at $P=0.05 ; \mathrm{S}_{\mathrm{R}}-$ standard deviation from the range

Data in Table 5 document how important the inoculum quality is. When different inocula are used, not only the rate of anaerobic degradability but also the obtained values for various sources of the tested sample are different. It is, however, crucial that the same order of anaerobic degradability is always maintained in all used inocula.

The results of acid hydrolysis in Table 6 show that the results of labile fraction LPI determination had the widest range; in contrast, the results of stable fraction LPIII had a much smaller range. It confirms our opinion that we cannot assess solely fraction LPI as a crucial criterion as Kolár et al. (2010) did. Much better information is provided by the sum of LPI and LPII fractions, even though in comparison with the results of anaerobic digestion it is only an orientative result.

Table 6. Anaerobic degradability and acid hydrolysis of the administered feed during 45 days of experiment.

\begin{tabular}{|c|c|c|c|c|c|c|c|c|}
\hline & \multirow{2}{*}{ Feed } & \multicolumn{4}{|c|}{ Sample collection } & \multirow{2}{*}{$\mathrm{R}$} & \multirow{2}{*}{$\mathrm{S}_{\mathrm{R}}$} & \multirow{2}{*}{$\mathrm{L}_{1,2}$} \\
\hline & & 3.11 .2010 & 6.11 .2010 & 14.11 .2010 & 18.11 .2010 & & & \\
\hline \multirow{2}{*}{$\operatorname{Dc}\left(\% \mathrm{C}_{\text {tot }}\right)$} & A & 55.8 & 48.3 & 60.4 & 56.7 & 12.1 & 5.8 & $55 \pm 311.1$ \\
\hline & $\mathrm{B}$ & 55.3 & 45.2 & 61.4 & 53.2 & 16.2 & 7.8 & $53.8 \pm 14.9$ \\
\hline \multirow{2}{*}{$\operatorname{LPI}\left(\% \mathrm{C}_{\mathrm{tot}}\right)$} & A & 35.4 & 47.6 & 39.8 & 38.2 & 12.2 & 5.8 & $40.2 \pm 11.2$ \\
\hline & $\mathrm{B}$ & 34.9 & 41.7 & 40.1 & 41.1 & 6.8 & 3.3 & $39.4 \pm 6.3$ \\
\hline \multirow{2}{*}{ LPII $\left(\% \mathrm{C}_{\text {tot }}\right)$} & A & 38.4 & 32.9 & 30.8 & 34.7 & 7.6 & 3.6 & $34.2 \pm 7$ \\
\hline & $\mathrm{B}$ & 37.8 & 33.2 & 31.9 & 32.3 & 5.9 & 2.8 & $33.8 \pm 5.4$ \\
\hline \multirow{2}{*}{ LPIII ( $\%$ Ctot $)$} & A & 26.2 & 23.5 & 29.4 & 27.1 & 5.9 & 2.8 & $26.5 \pm 5.4$ \\
\hline & $\mathrm{B}$ & 27.3 & 24.1 & 28 & 26.6 & 3.9 & 1.9 & $26.5 \pm 3.6$ \\
\hline
\end{tabular}

$\mathrm{D}_{\mathrm{c}}$ - anaerobic degradability; A - $1+2$ sampling; $\mathrm{B}-3+4$ sampling; $\mathrm{R}$ - range, $\mathrm{L}_{1,2}$ - interval of reliability of the mean at $P^{\mathrm{c}}=0.05 ;\left(\mathrm{L}_{1,2}=\mathrm{x} \pm \mathrm{K}_{\mathrm{n}} \cdot \mathrm{R} ; \mathrm{K}_{\mathrm{n}}(\mathrm{n}=4)=0.48(P=0.05)\right) ; \mathrm{S}_{\mathrm{R}}-$ standard deviation from the range $\left(\mathrm{S}_{\mathrm{R}}=\mathrm{k}_{\mathrm{n}} \cdot \mathrm{R} ; \quad \mathrm{k}_{\mathrm{n}}(\mathrm{n}=8)=\right.$ 0.92); LPI - labile fraction; LPII - semi-labile fraction; LPIII - stable fraction

Comparing Tables 7 and 8, it is evident that the time span of 30 days of lactation did not influence labile fraction LPI of acid hydrolysis at all but the sum of fractions LPI and LPII indicates that stable fraction LPIII was slightly higher in period 2, i.e. the longer lactation period was reflected in better utilization of labile organic matters in the digestive tract of animals. The range of results in Tables 7 and 8 is small because statistical outliers were excluded. However, there was a difference of about 5\%. In anaerobic digestion the lactation 
duration resulted in about $7 \%$ better utilization of feed. These are small differences and this is the reason why Table 9 contains the consistency test of results of anaerobic digestion in period 1 (Table 7) and in period 2 (Table 8). Lord's test (Eckschlager et al. 1980) was used for testing:

$\mu=\frac{\left|\overline{\mathrm{x}}_{\mathrm{A}}-\overline{\mathrm{x}}_{\mathrm{B}}\right|}{\mathrm{R}_{\mathrm{A}}+\mathrm{R}_{\mathrm{B}}}$

and critical values of $\mu$, for $P=0.05$ and for $\mathrm{n}=9$. Because the determined values $\mu=$ 0.983 and $\mu=0.404$ are higher than the critical value $\mu=0.167$, it is possible to state

Table 7. Anaerobic degradability and acid hydrolysis of excrements in initial period 1 with feed $\mathrm{A}$ of the first half attempt and with feed $\mathrm{B}$ of the second half attempt.

\begin{tabular}{lccccccc}
\hline & Feed & $\mathrm{n}$ & $\mathrm{R}$ & $\mathrm{k}_{\mathrm{n}}$ & $\mathrm{S}_{\mathrm{R}}$ & $\mathrm{t}_{\mathrm{a}(\mathrm{n}-1)} / \sqrt{\mathrm{n}}$ & $\mathrm{L}_{1,2}$ \\
\hline Dc $\left(\% \mathrm{C}_{\text {tot }}\right)$ & $\mathrm{A}$ & 9 & 3.3 & 0.34 & 1.12 & 0.77 & $32.0 \pm 0.9$ \\
\cline { 2 - 8 } & $\mathrm{B}$ & 8 & 6.8 & 0.35 & 2.38 & 0.84 & $31.0 \pm 2.0$ \\
\hline \multirow{2}{*}{ LPI $\left(\% \mathrm{C}_{\text {tot }}\right)$} & $\mathrm{A}$ & 9 & 0.2 & 0.34 & 0.07 & 0.77 & $3.8 \pm 0.0$ \\
\cline { 2 - 8 } & $\mathrm{B}$ & 10 & 0.3 & 0.32 & 0.1 & 0.72 & $3.8 \pm 0.0$ \\
\hline \multirow{2}{*}{ LPII $\left(\% \mathrm{C}_{\text {tot }}\right)$} & $\mathrm{A}$ & 8 & 2 & 0.35 & 0.7 & 0.84 & $33.2 \pm 0.6$ \\
\cline { 2 - 8 } & $\mathrm{B}$ & 8 & 2.1 & 0.35 & 0.73 & 0.84 & $35.1 \pm 0.6$ \\
\hline \multirow{2}{*}{ LPIII $\left(\% \mathrm{C}_{\text {tot }}\right)$} & $\mathrm{A}$ & 10 & 2.4 & 0.32 & 0.77 & 0.72 & $63.0 \pm 0.6$ \\
\cline { 2 - 8 } & $\mathrm{B}$ & 10 & 2.2 & 0.32 & 0.7 & 0.72 & $61.1 \pm 0.5$ \\
\hline
\end{tabular}

$\mathrm{D}_{\mathrm{c}}$ - anaerobic degradability; $\mathrm{A}-1+2$ sampling; $\mathrm{B}-3+4$ sampling; $\mathrm{R}$ - range, $\mathrm{L}_{1,2}$ - interval of reliability of the mean at $P=0.05 ; \mathrm{S}_{\mathrm{R}}-$ standard deviation from the range; LPI - labile fraction; LPII - semi-labile fraction; LPIII - stable fraction; $\mathrm{n}$ - number of samples after the exclusion of outliers; $\mathrm{k}_{\mathrm{n}}$ - coefficient for the calculation; $\mathrm{S}_{\mathrm{R}}$ - standard deviation from the range; $\mathrm{t}_{\mathrm{a}(\mathrm{n}-1)} / \sqrt{\mathrm{n}}_{\mathrm{n}}^{\mathrm{n}}$ - coefficient from Student's $t$-distribution for $P=0.05$

Table 8. Anaerobic degradability and acid hydrolysis of excrements in period 2 longer by 30 days of lactation compared to period 1 with feed A and with feed $B$.

\begin{tabular}{lrrrrrrr}
\hline & Feed & $\mathrm{n}$ & $\mathrm{R}$ & $\mathrm{k}_{\mathrm{n}}$ & $\mathrm{S}_{\mathrm{R}}$ & $\mathrm{t}_{\mathrm{a}(\mathrm{n}-1)} / \mathrm{Jn}$ & $\mathrm{L}_{1,2}$ \\
\hline \multirow{2}{*}{$\mathrm{Dc}\left(\% \mathrm{C}_{\text {tot }}\right)$} & $\mathrm{A}$ & 9 & 2.8 & 0.34 & 0.95 & 0.77 & $26.1 \pm 0.7$ \\
\cline { 2 - 8 } & $\mathrm{B}$ & 9 & 3.1 & 0.34 & 1.05 & 0.77 & $26.6 \pm 0.8$ \\
\hline \multirow{2}{*}{ LPI $\left(\% \mathrm{C}_{\text {tot }}\right)$} & $\mathrm{A}$ & 10 & 0.2 & 0.32 & 0.06 & 0.72 & $3.7 \pm 0.0$ \\
\cline { 2 - 8 } & $\mathrm{B}$ & 10 & 0.2 & 0.32 & 0.06 & 0.72 & $3.8 \pm 0.0$ \\
\hline \multirow{2}{*}{ LPII $\left(\% \mathrm{C}_{\text {tot }}\right)$} & $\mathrm{A}$ & 8 & 1.9 & 0.35 & 0.66 & 0.84 & $29.1 \pm 0.6$ \\
\cline { 2 - 8 } & $\mathrm{B}$ & 9 & 2.2 & 0.34 & 0.75 & 0.77 & $28.3 \pm 0.6$ \\
\hline \multirow{2}{*}{ LPIII $\left(\% \mathrm{C}_{\text {tot }}\right)$} & $\mathrm{A}$ & 10 & 2.8 & 0.32 & 0.9 & 0.72 & $67.2 \pm 0.6$ \\
\cline { 2 - 8 } & $\mathrm{B}$ & 9 & 2.5 & 0.34 & 0.85 & 0.77 & $67.9 \pm 0.7$ \\
\hline
\end{tabular}

D - anaerobic degradability; $\mathrm{A}-1+2$ sampling; $\mathrm{B}-3+4$ sampling; $\mathrm{R}$ - range, $\mathrm{L}_{1,2}$ - interval of reliability of the mean at $P=0.05 ; \mathrm{S}_{\mathrm{R}}-$ standard deviation from the range; LPI - labile fraction; LPII - semi-labile fraction; LPIII - stable fraction; $\mathrm{n}$ - number of samples after the exclusion of outliers; $\mathrm{k}_{\mathrm{n}}$ - coefficient for the calculation; $\mathrm{S}_{\mathrm{R}}$ - standard deviation from the range; $\mathrm{t}_{\mathrm{a}(\mathrm{n}-1)} / \mathrm{V}_{\mathrm{n}}^{\mathrm{n}}$ - coefficient from Student's $t$-distribution for $P=0.05$ that the revealed apparently small difference in results is significant at $P=0.05$ and the null hypothesis can be rejected. The longer lactation period had a significant influence on better utilization of organic matter in the digestive tract of experimental animals.

We were convinced that the lower appetite of animals to feed intake in the puerperal period would be reflected in the self-regulation of the digestive tract so that the higher biochemical activity of the organism would ensure better utilization of feed ration. This hypothesis was not confirmed; on the other hand, with time elapsing from parturition the organism regenerates and the enzymatic activity of the digestive tract of experimental animals is gradually increasing.

The calculation of the consistency tests of results in period 1 and 2 could show that the results of differences in stable fraction LPIII are significant at $P=0.05$; so it would theoretically be possible that difficult determination of anaerobic digestion could be replaced by an easier method of acid hydrolysis. But sensitivity of the method is problematic because in other 
Table 9. Evaluation of the influence of lactation duration on a change in the results of anaerobic degradability of excrements by testing the consistency of results in period 1 and period 2 differing in 30 days of lactation, feed $\mathrm{A}$ and feed B.

\begin{tabular}{cccccc}
\hline $\mathrm{X}_{\mathrm{A}}$ & $\mathrm{X}_{\mathrm{B}}$ & $\mathrm{R}_{\mathrm{A}}$ & $\mathrm{R}_{\mathrm{B}}$ & $\mu$ & $\mu_{\text {crit }}$ \\
\hline 32 & 26 & 3.3 & 2.8 & 0.983 & \multirow{2}{*}{0.167} \\
\cline { 1 - 4 } 31 & 27 & 6.8 & 3.1 & 0.404 & \\
\hline
\end{tabular}

$\mu_{\text {crit }}-$ critical values of $\mu\left(\mu_{\text {crit }}\right.$ for $\mathrm{n}=9$ and $\left.P=0.05\right)$ experiments we obtained non-significant results of the used acid hydrolysis of excrements. Acid hydrolysis of the excrement can replace expensive determination of anaerobic degradability of the excrement.

\section{Acknowledgement}

The study was supported by Grant of Ministry of Agriculture of the Czech Republic (Project No. QJ1230066). We are very grateful for this support.

\section{References}

Baresi L, Mah R, Ward D, Kaplan L 1978: Methanogenesis from acetate: Enrichment studies. Appl Environ Microbiol 36: 186-197

Blair GJ, Lefroy RDB, Lisle L 1995: Carbon fractions based on their degree of oxidation and the development of a carbon management index for agricultural systems. Aust J Agric Res 46: 1459-1466

Chan KY, Bowman A, Oates A 2001: Oxidizable organic carbon fractions and soil quality changes in an oxic paleustalf under different pasture leys. Soil Sci 166: 61-67

Eckschlager K, Horsák I, Kodejs Z 1980: Evaluation of Analytical Results and Methods (in Czech). SNTL Praha, $223 \mathrm{p}$.

Garcia JL, Patel BKC, Ollivier B 2000: Taxonomic, phytogenetic and ecological diversity of methanogenic. Archaea Anaerobe 6: 205-226

Gijzen HJ 1998: Anaerobic Digestion of Cellulosic Waste by a Rumen-derived Process. Dissertation, University Nijmegen, Netherlands, 173 p.

Gujer W, Zehnder AJB 1983: Conversion processes in anaerobic digestion. Water Sci Technol 15: 127-167

Hwang S, Lee Y, Yang K 2001: Maximisation of acid production in partial acidogenesis of swine wastewater. Biotechnol Bioeng 75: 521-529

ISO 14235 1998: Soil Quality, Determination of Organic Carbon by Sulfochromic Oxidation, International Organization for Standardization, Geneva.

Kalyuzhnyi S, Veeken A, Hamelers B 2000: Two-particle model of anaerobic solid-state fermentation. Water Sci Technol 41: 43-50

Kononová M, Bělčíková NP 1963: Short fractionation method of humic substance in mineral soils (in Russian), in: Organiceskoje veščestvo počvy (Soil Humic Substances), Moskva, 313 p.

Kaseng K, Ibrahim K, Pancerselvam SV, Hassan RS 1992: Extracellular enzymes and acidogen profiles of a laboratory-scale two-phase anaerobic digestion system. Process Biochem 27: 43-47

Kolář L, Frelich J, Brouček J, Kužel S, Borová - Batt J, Peterka J, Šlachta M, Volfová K, Pezlarová J, Hřebečková J, Čechová V 2010: Anaerobic degradability of organic matter of cattle faeces and a possibility of its utilization. Czech J Anim Sci 55: 538-547

Körschens M, Schulz E, Böhm R 1990: Hot water soluble C and N in the soil as a criterion for microbiology (in German). Jena 145: 303-311

Rovira P, Vallejo VR 2002: Labile and recalcitrant pools of carbon and nitrogen in organic matter decomposing at different depths in soil: an acid hydrolysis approach. Geoderma 107: 109-141

Salminen E, Rintala J, Lokshima LY, Vavilin VA 2000: Anaerobic batch degradation of solid poultry slanghterhouse waste. Water Sci Technol 41: 33-41

Shirato Y, Yokozawa M 2006: Acid hydrolysis to partition plant material into decomposable and resistant fractions for use in the Rothamsted carbon model. Soil Biol Biochem 38: 812-816

Straka F, Dohanyos M, Zábranská J, Dědek J, Malijevský A, Novák J, Oldřich J 2009: Biogas (in Czech). GAS, Ríčany u Prahy, 517 p.

Süssmuth R, Doser Ch, Lueders T 1999: Determination of the biological biodegradability of organic substances under anaerobic conditions using the Oxi Top Control measuring system. Appl. Rep. 0600412 e, Universität Hohenheim, Institute für Mikrobiologie, Wissenschaftlich-technische Werkstäten GmbH\&Co., KG Weilheim, Germany

Walkley A 1947: A critical examination of a rapid method for determining organic carbon in soils. Soil Science 63: $251-263$ 